\title{
SISWA MEMANFAATKAN SOSIAL MEDIA DALAM BERWIRAUSAHA PADA MASA PANDEMI COVID-19
}

\author{
Eliza $^{1}$ dan Jumiatul Mulya ${ }^{2}$ \\ 'Program Studi Akuntansi, Fakultas Ekonomi dan Bisnis, Universitas Putra Indonesia "YPTK" \\ ${ }^{2}$ Program Studi Manajemen, Sekolah Tinggi Ilmu Ekonomi Perdagangan \\ 1'eliza@upiyptk.ac.id*,2jumiatulmulya89@gmail.com
}

\begin{abstract}
ABSTRAK. Pandemi tidak menjadi penghalang bagi siswa untuk menggali ilmu pengetahuan khususnya berwirausaha sebagai bekal dalam menghadapi tantangan yang semakin pesat terhadap era digitalisasi dan juga literasi Pandemi tidak menjadi penghalang untuk terus mengembangkan kreatifitas dalam diri siswa terutama tentang jiwa berwirausaha sebagai. SMA Negeri 2 Padang Panjang adalah peserta didik yang merupakan kelompok kecil dari masyarakat yang akan menghadapi dunia kerja untuk memenuhi kebutuhan fianasial mereka. Saat ini, pengerakan dunia industri sangat cepat, sehingga para peserta didik tersebut harus mampu mengikuti perkembangan zaman dengan membekali diri menjadi sosok yang kreatif, inovatif, berpikir maju (tidak hanya untuk mencari lapangan pekerjaan saja, tetapi mampu menciptakan lapangan pekerjaan bagi orang) agar menjadi sosok yang mandiri dan tangguh menghadapi tantangan. Adapun tujuan dari edukasi kepada peserta didik untuk mengembangkan jiwa wirausaha sejak dini agar dapat mandiri dan tangguh menghadapi tantangan di masa depan yang mampu mengembangkan diri menjadi produktif, kreatif, inovatif sejak dini yang dimulai dari bagian kecil yaitu melalui media online dalam menghadapi situasi dan kondisi pandemi covid-19. Metode yang digunakan dalam kegiatan ini adalah sosialisasi, diskusi, serta tanya jawab tentang membangun jiwa wirausaha secara online tersebut secara virtual zoom cloud meeting, mengingat situasi dan kondisi saat ini untuk mengurangi mobilitas dan menjaga segala sesuatunya agar tetap aman pada semua pihak yang terkait dalam kegiatan ini. Dengan adanya sosialisasi ini diharapkan peserta didik yang mengikuti kegiatan ini sejak dini mampu mengembangkan diri untuk menjadi sosok entrepreneurship dalam menciptakan sesuatu sesuai dengan skill yang dimiliki untuk menghadapi tantangan masa depan yang semakin pesat dan persaingan ketat pada revolution industry 4.0 dan era society 5.0.
\end{abstract}

Kata Kunci: Siswa; Wirausaha; Sosial Media; Pandemi

ABSTRACT. The pandemic does not become a barrier to continue to develop creativity in oneself, especially regarding the entrepreneurial spirit as a provision to face the increasingly rapid challenges of the era of digitalization and literacy. SMA Negeri 2 Padang Panjang are students who are a small group of people who will face the world of work to meet their financial needs, currently the industrial world is moving very fast, so these students must be able to keep up with the times by equipping themselves to be creative figures. , innovative, think ahead (not only to find jobs, but able to create jobs for people) in order to become an independent and resilient figure in facing challenges. The purpose of education for students is to develop an entrepreneurial spirit from an early age so that they can be independent and resilient in facing future challenges that are able to develop themselves to be productive, creative, innovative from an early age starting from a small part, namely through online media in dealing with pandemic situations and conditions. covid-19. The methods used in this activity are socialization, discussion, and questions and answers about building the entrepreneurial spirit online by virtual Zoom Cloud Meeting, considering the current situation and conditions to reduce mobility and keep things safe for all parties involved in the activity. this. With this socialization, it is hoped that students who take part in this activity from an early age will be able to develop themselves to become entrepreneurial figures in creating something according to their skills to face the increasingly rapid future challenges and fierce competition in industrial revolution 4.0 and society 5.0 era.

Keywords: Students; Entrepreneurial Spirit; Online Media; Pandemic

\section{PENDAHULUAN}

Indonesia benar-benar membutuhkan seseorang yang mampu membuka kesempatan atau peluang untuk bekerja dibandingkan untuk seseorang yang berpengetahuan, tetapi mesti menghadapi antrian dalam para pencari kerja. Ilmu pengetahuan dan teknologi kian hari makin berkembang sangat pesat, apalagi tingkat pertumbuhan pembangunan dan industri telah melewati masa pembaharuan di era serba digital. Era yang serba digital ini banyak sekali bentuk kemudahan dalam segala bidang, namun hal tersebut membuat peran tenaga kerja manusia semakin rendah karena secara tidak langsung SDM sudah digantikan dengan mesin dan teknologi. Lebih lanjut, dalam hal ini pembahasan wirausaha menurut Schumpeter dalam Buchari (2008) bahwa wirausaha adalah orang yang mendobrak sistem ekonomi yang ada dengan memperkenalkan barang dan jasa yang baru, dengan menciptakan bentuk organisasi baru atau mengolah bahan baku baru.

Menurut Rinaldy dan Yosi(2021), pertumbuhan ekonomi Kota Padang tahun 2020 mengalami perlambatan cukup signifikan sebesar $-1,86 \%$ jika dibandingkan dengan 5,65\% (2019), meskipun perlambatan ini masih jauh dibawah rata-rata nasional dan Provinsi Sumatera Barat (menurut perkiraan sementara). Terdapat 8 sektor yang mengalami 
penurunan nilai berdasarkan data PDRB Kota Padang tahun 2020, yaitu: sektor pertambangan dan penggalian, sektor pengadaan listrik dan gas, sektor konstruksi, sektor perdagangan besar dan eceran, reparasi mobil dan sepeda motor, sektor transportasi dan pergudangan, sektor penyediaan akomodasi dan makan/minum, sektor jasa perusahaan, dan sektor jasa lainnya. Sektor penyediaan akomodasi dan makan minum, mengalami penurunan dari $\mathrm{Rp}$. 935,09 M (2019) menjadi Rp. 745,82 M (2020), atau turun sekitar Rp. 189,27 M (sekitar 20,24\%).

Salah satu kota yang ada di daerah Sumatera Barat adalah Padang Pariaman. Menurut Langgam. id (2020), Pemerintah Kota Padang Panjang terus meningkatkan kualitas jaringan internet. Hal ini dilakukan untuk mendorong peningkatan transaksi digital oleh masyarakat dan pedagang.

Sosial Media merupakan sebuah media berbasis kecanggihan teknologi yang diklasifikasikan dari berbagai bentuk, seperti majalah, forum internet, weblog, blog sosial, microblogging, wiki, siniar, foto atau gambar, video, peringkat dan bookmark sosial. Dengan menerapkan satu set teori dalam bidang media penelitian (kehadiran sosial, media kekayaan) dan proses sosial (self-presentasi, self-disclosure), Kaplan dan Haenlein menciptakan skema atau klasifikasi untuk berbagai jenis media sosial (Horizons Bisnis, 2010). Disisi lain, terkait sosial media, media online juga termasuk social media, yang merupakan sebuah sarana untuk berkomunikasi secara online melalui website dan aplikasi yang hanya bisa diakses dengan internet. Berisikan teks, suara, foto dan video. Pengertian media online secara umum mencakupi semua jenis situs website dan aplikasi, termasuk situs berita, situs perusahaan, situs lembaga/instansi, blog, forum komunitas, media sosial situs jualan (e-commerce/online store) dan aplikasi chattingan (Romli, 2012)

Pengembangan jiwa wirausaha harus dilakukan mulai dari hal yang kecil, yaitu melalui peserta didik, dengan lingkup kecil adalah sekolah melalui media online untuk membentuk pola pikir peserta didik tersebut, mengasah kreatifitas mereka untuk inovatif menciptakan sesuatu yang baru sesuai dengan keahlian yang mereka miliki.

Menghadapi hal tersebut tentu perlunya pemberian pemahaman kepada generasi muda khususnya kepada para peserta didik setara SMA, untuk menjadi pribadi yang inovatif dan kreatif sejak dini agar mereka bisa mandiri secara finansial untuk memenuhi kebutuhan hidupnya. Salah satu bentuk dari jiwa yang produktif adalah merubah pandangan dan pola pikir untuk menjadikan diri sendiri sebagai pribadi yang mandiri dan tangguh dan siap menghadapi tantangan di masa pandemi dan masa depan. Di era yang canggih dan perkembangan teknologi dan industri yang telah memasuki era 4.0 dan juga era society 5.0 hendaknya mampu menciptakan lapangan pekerjaan sendiri dengan inovatif, kreatifitas yang dimiliki, sehingga tidak hanya memberikan manfaat untuk diri sendiri, tetapi untuk banyak orang.

Mengingat pentingnya pemahaman untuk dapat mengembangkan jiwa inovatif dan kreatif sajak dini kepada para peserta didik SMA agar mereka dapat mandiri secara finansial, maka kami dari tim PKM UPI YPTK Padang akan memberikan pembinaan dan edukasi kepada para peserta didik tersebut, begitu pentingnya untuk membangun jiwa inovatif dan kreatif sejak dini dan di era serba digital ini, seuai dengan perkembangan zamannya.

Disini kami dari tim PKM akan mencoba berbagi ilmu dan pengalaman kepada para peserta didik dan memberikan pemahaman tentang jiwa wirausaha yang di mulai dari lingkungan sekolah melalui koperasi siswa agar mereka mengembangkan potensi diri yang mereka miliki. Memiliki jiwa wirausaha yang inovatif dan kreatif artinya segala sesuatu akan nampak seperti peluang usaha dan membuka lapangan pekerjaan tidak hanya bagi dirinya sendiri, namun juga bagi orang lain, sehingga memberikan manfaat yang besar tidak hanya bagi diri sendiri, tetapi juga banyak orang.

Oleh karena itu dengan memperhatikan permasalahan yang terjadi di masyarakat, serta minimnya ilmu dan pengalaman yang mereka miliki, dan memberikan pembelajaran yang berarti, bagaimana mampu membuka lapangan pekerjaan sendiri, bukan hanya selalu berpikir hanya mencari pekerjaan bagi kalangan remaja khususnya peserta didik SMA, maka kami dari Tim PKM UPI YPTK Padang melakukan kegiatan ini di sekolah SMA Negeri 2 Padang Panjang. Semoga kelompok kecil dari masyarakat ini bisa mengikuti perubahan teknologi di era revolusi industri (revolution industry) dan era society dengan cermat dan bijak.

Sebelumnya kegiatan ini juga pernah dilakukan pelatihan kewirausahaan melalui pendanaan DRPM, Direktorat Jenderal Riset dan Pengembangan KEMENRISTEKDIKTI Skema Program Kemitraan Masyarakat Stimulus (PKMS) tahun 2019 dan telah dipublikasi melalui URL http://jurnal.unpad.ac.id/ dharmakarya/article/view/24118/12137, begitu juga video kegiatan dari PKMS tersebut yang telah memiliki Hak Kekayaan Intelektual dengan nomor pencatatan HAKI 000209937. Selain itu, dilakukan juga sosialisasi tentang membangun jiwa wirausaha dengan media online kepada peserta didik dan dipublikasi melalui URL https://jurnal.unpad.ac.id/ dharmakarya/article/view/33256/15522. 


\section{METODE}

Metode pelaksanaan kegiatan ini adalah secara virtual melalui online dengan menggunakan platform zoom cloud meeting, penggunaan internet secara umum, dan pemanfaatan WhatsApp.

Sosialisasi ini dilaksanakan Jarak Jauh di tempat masing-masing dengan menggunakan sarana virtual aplikasi zoom cloud meeting, dikarenakan masa pandemi covid-19.

\section{Lingkup Pelaksanaan}

1. Menyediakan materi tentang kegiatan yang akan digunakan bagi peserta kegiatan sosialisasi dan edukasi.

2. Memberikan pemberdayaan tentang kepada peserta didik agar mampu menjadi pribadi yang bermanfaat bagi lingkungannya, imajinatif, dan inovatif, bertanggung jawab dan responsif dalam berhubungan dengan orang lain.

3. Mengajukan proposal kegiatan sebagai bahan dasar pelaksanaan kegiatan, serta acuan untuk mensukseskan kegiatan sosialisasi dan edukasi.

Dalam pelaksanaan kegiatan, metode dan langkah yang dilakukan akan dijelaskan, sebagai berikut:

1. Melakukan rapat koordinasi bersama Tim PKMBM UPI YPTK Padang dalam waktu yang terukur dan konsisten.

2. Memberikan pembelajaran tentang bagaimana membangun jiwa wirausaha melalui media online pada masa pandemi covid-19 bagi peserta didik SMA Negeri 2 Padang Panjang.

3. Melakukan survey lokasi dengan cara mendatangi langsung tempat atau lokasi kegiatan. Kegiatan ini diakhiri dengan membuat kerjasama berupa pengagendaan dan jadwal PKM-BM.

4. Mendata dengan baik seluruh peserta kegiatan dan fasilitas yang dapat digunaan selama kegiatan.

5. Merealisasikan seluruh agenda yang telah direncanakan secara tertulis dalamnaskah proposal kegiatan PKM-BM. Kemudian menyerahkan kepada LPPM UPI YPTK Padang sesuai dengan arahan prosedur yang telah ditentukan.

\section{METODE}

Kegiatan pengabdian kepada masyarakat ini dilakukan dengan cara membagi informasi dengan cara mensosialisasikan kepada peserta didik dalam membangun jiwa wirausaha sejak dini melalui media online agar dapat mandiri secara finansial pada masa pandemi covid-19. Berikut implementasi kegiatan yang dapat diuraikan:

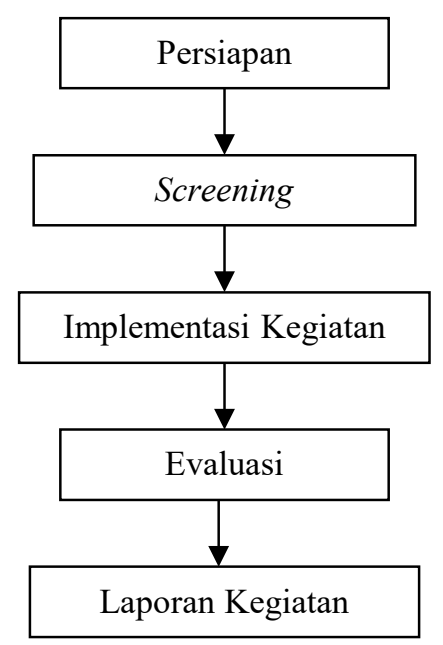

Gambar. 1 Diagram Proses Implementasi Kegiatan

\section{Persiapan}

Persiapan dari kegiatan ini mencakup beberapa prosedur:

a. Menyiapkan materi

b. Survei lokasi

c. Mengurus surat-surat perizinan

d. Membuat proposal dan proses persetujuan lokasi pengabdian kepada masyarakat.

\section{Screening}

Setelah memaksimalkan persiapan, screening kemudian menjadi agenda selanjutnya. Ada beberapa tahap yang dilakukan:

a. Menyiapkan pembicara dan panitia sebelum acara

b. Memastikan semua alat-alat siap dibawa ke lokasi

c. Memastikan semua kebutuhan acara seperti transportasi dan spanduk

\section{Implementasi Kegiatan}

Tindakan atau pelaksanaan dari rencana yang sudah disusun dalam sosialisai dan edukasi yang diberikan kepada peserta didik di SMA Negeri 2 Padang Panjang, diantaranya:

a. Pemberian materi mengenai jiwa wirausaha kepada peserta didik di SMA Negeri 2 Padang Panjang.

b. Pemberian materi mengenai pemanfaatan media online untuk menumbuh kembangkan jiwa wirausaha kepada peserta didik di SMA Negeri 2 Padang Panjang.

\section{Evaluasi}

a. Semua anggota PKM diharapkan hadir.

b. Pelaksananya seluruh kegiatan sosialisasi dengan lancar dan sukses.

c. $85 \%$ semua anggota PKM harus memahami tentang jiwa wirausaha dan media online.

\section{Laporan Kegiatan}

Untuk mencapai tujuan yang akan diinginkan, maka dalam realisasi program tersebut diharapakan mitra dapat berpartisipasi dengan kegiatan, sebagai berikut: 
a. Menjadi peserta sosialisasi, menerima teori, konsep, diskusi tanya jawab, serta hal-hal lain yang diberikan selama proses kegiatan berlangsung.

b. Menyediakan tempat dan fasilitas yang dibutuhkan selama proses kegiatan berlangsung.

\section{HASIL DAN PEMBAHASAN}

Kegiatan ini dilaksanakan dengan kolaborasi antara peserta didik (SMA Negeri 2 Padang Panjang) dengan tim pelaksana yang langsung menjadi pemateri yang telah dilaksanakan di SMA Negeri 2 Padang Panjang berjalan lancar dan sukses sesuai target dan luaran yang ingin dicapai dari kegiatan pengabdian kepada masyarakat ini.

Pengabdian Kepada Masyarakat di sekolah ini sangat bermanfaat khususnya bagi peserta didik SMA Negeri 2 Padang Panjang untuk membekali diri dari sekarang agar mampu menghadapi setiap tantangan yang ada di masa depan, apalagi saat ini kita sudah dalam era revolusi industry 4.0 dan era society 5.0 yang memang harus dihadapi, sehingga pada saat peserta didik tersebut sudah menamatkan sekolah, tidak fokus hanya pada mencari pekerjaan, tetapi bagaimana bisa menciptakan lapangan pekerjaan sendiri dengan memulai dari hal yang paling kecil.

Kegiatan ini membuat para peserta didik sangat antusias mengikutinya, terdapat dari para peserta didik tersebut mengajukan pertanyaan tentang bagaimana membangun jiwa usaha sejak dini, bagaimana memotivasi diri, bagaimana memanfaatkan media online dalam berwirausaha, dan masih banyak pertanyaan lainnya yang mereka ajukan sebagai sharing mereka dengan kegiatan ini dan juga tema yang memang cocok untuk mereka semua.

Berikut dapat dijabarkan beberapa hal yang telah dicapai dari kegiatan Pengabdian Kepada Masyarakat ini, di antaranya:

\section{Bagi Peserta Didik}

Kegiatan pengabdian kegiatan masyarakat ini bermanfaat bagi peserta didik dan juga orang tua dari peserta didik, dengan adanya sosialisasi dan edukasi ini dapat membuka mereka tentang dunia usaha yang dapat bertahan sekarang ini, yaitu adanya sebuah ide kreatif yang beda dengan lainnya yang sudah lebih dahulu tercipta oleh orang kebanyakan. Kegiatan ini akan membuka cakrawala berpikir peserta didik untuk menghadapi masa depan dengan tantangan yang tidak seperti mereka bayangkan saat ini, tetapi tantangan yang harus mampu mereka hadapi dan bagaimana mereka bijak dalam menghadapi tantangan tersebut dengan berpikir maju dalam menemukan peluang-peluang besar yang harus dikembangkan dalam mengatasi berbagai tantangan tersebut, sehingga mereka harus menyiapkan diri, membekali diri dengan kreatif, inovatif, tangguh, mandiri, dan siap dalam tantangan nantinya akan menjadikan mereka sosok, salah satunya mampu menciptakan lapangan pekerjaan sendiri serta menjadi entrepreneurship sukses dan handal.

\section{Bagi Tim Pelaksana Pengabdian}

Bagi kami para dosen pelaksana pengabdian kepada masyarakat, kegiatan sosialisasi dan edukasi ini merupakan salah satu kegiatan wajib dalam memenuhi Tridharma Perguruan Tinggi, yang mana tujuannya adalah dapat memberi manfaat bagi masyarakat banyak sesuai dengan bidang keilmuan yang kami miliki. Kegiatan pengabdian kepada masyarakat ini dapat berjalan lancar dan juga mendapat dukungan dari berbagai pihak.

Lebih lanjut, berikut ini merupakan dokumentasi dari kegiatan pengabdian beserta materi yang diberikan kepada peserta didik SMA Negeri 2 Padang Panjang:

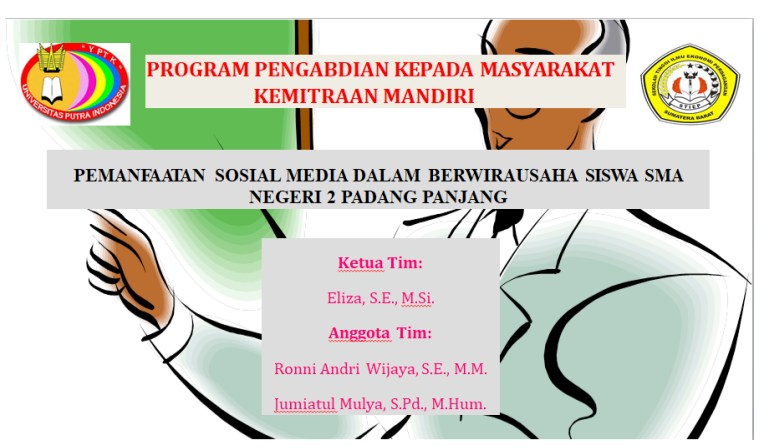

Gambar 1. Program PKM Kemitraan Mandiri

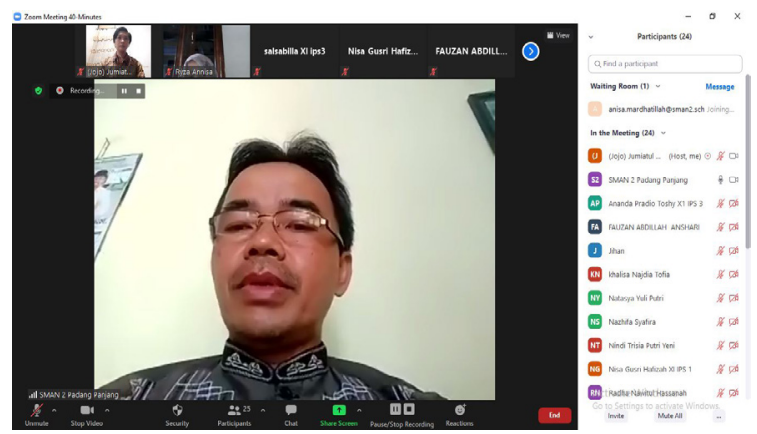

Gambar 2. Kata Sambutan Kepala SMA Negeri 2 Padang Panjang

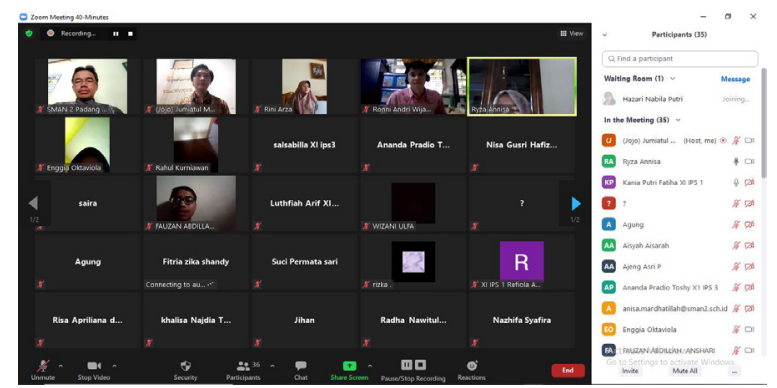

Gambar 3. Peserta Program PKM Kemitraan Mandiri 


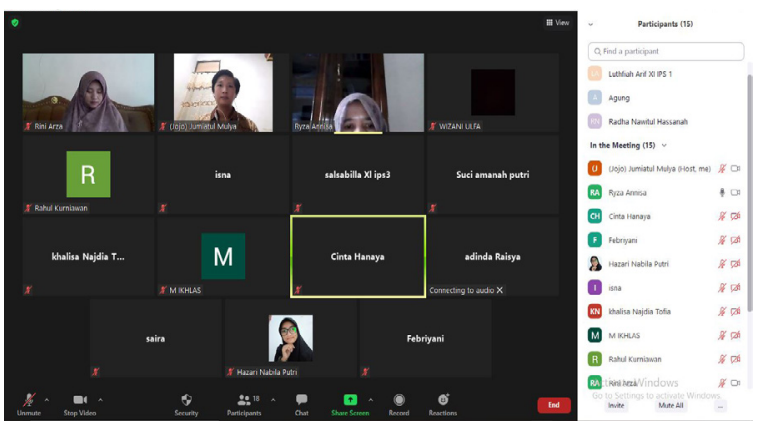

Gambar4. Peserta Program PKM Kemitraan Mandiri

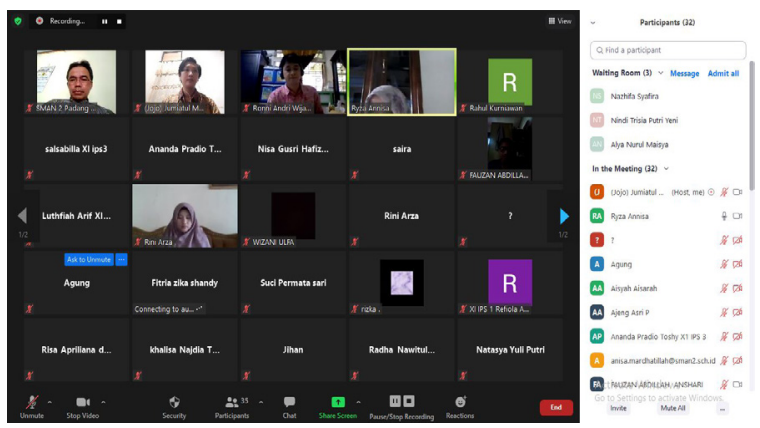

Gambar 5. Peserta Program PKM Kemitraan Mandiri

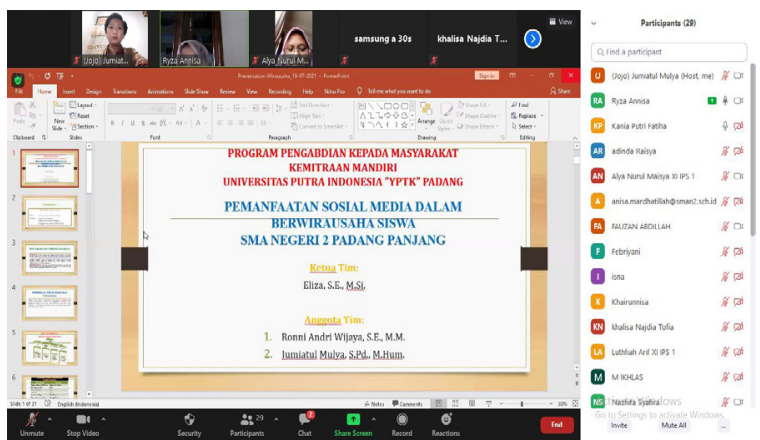

Gambar 6. Materi Wirausaha

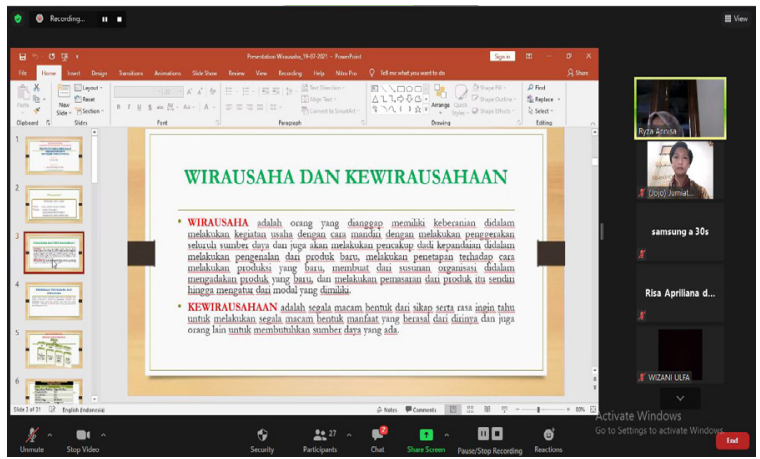

Gambar 7. Lanjutan Materi Wirausaha

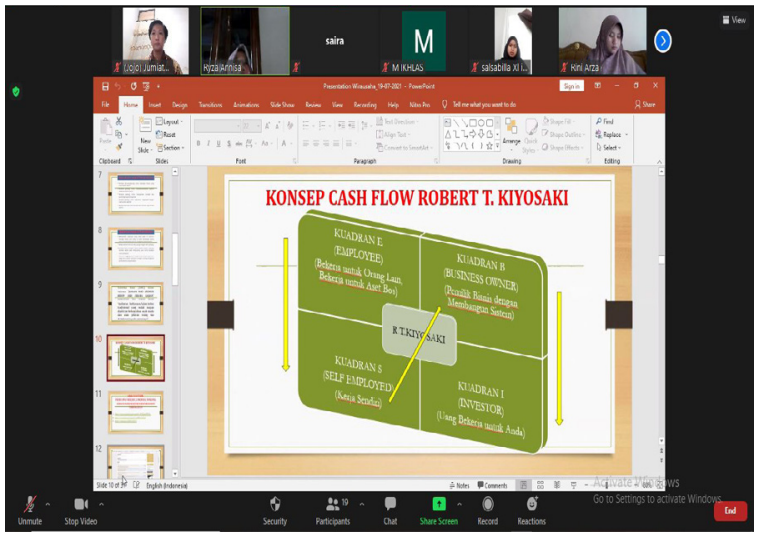

Gambar 8. Lanjutan Materi Wirausaha
Setelah melakukan pemberian materi kepada peserta didik SMA Negeri 2 Padang Panjang, kami langsung memberikan beberapa pertanyaan melalui google formulir yang sudah disiapkan. Berikut ini merupakan jawaban dari 35 orang siswa SMA Negeri 2 Padang Panjang.

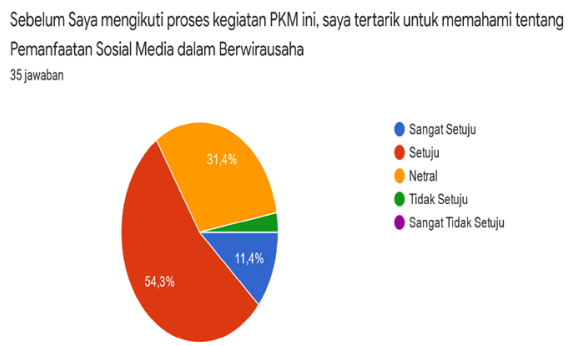

Gambar 9. Kuesioner Sebelum Mengikuti Kegiatan

Berdasarkan tabel diatas, dapat disimpulkan bahwa peserta didik SMA Negeri 2 Padang Panjang tertarik untuk memahami tentang pemanfaatan sosial media sebesar 54,3\% menjawab setuju.

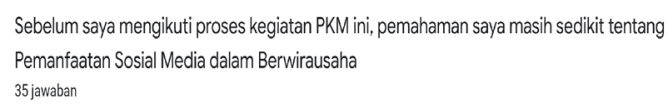

Sebelum saya mengikuti proses kegiatan PKM ini, pemahaman saya masih sedikit tentang Pemanfaatan Sosial Media dalam Berwirausaha 35 jawaban
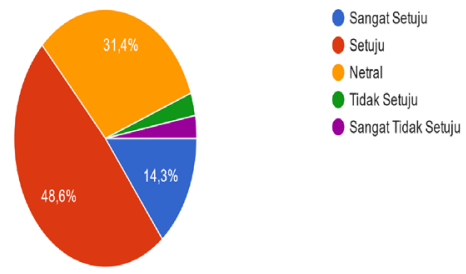

Gambar 10. Kuesioner Sebelum mengikuti Kegiatan

Tabel 9 merupakan kelanjutan dari pertanyaan yang diberikan kepada peserta didik SMA Negeri 2 Padang Panjang. Berdasarkan Tabel.9, dapat disimpulkan bahwa sebelum mengikuti kegiatan PKM, para peserta didik masih memiliki sedikit pemahaman terkait tentang pemanfaatan sosial media dalam berwirausaha sebesar 48,6\% menjawab setuju.
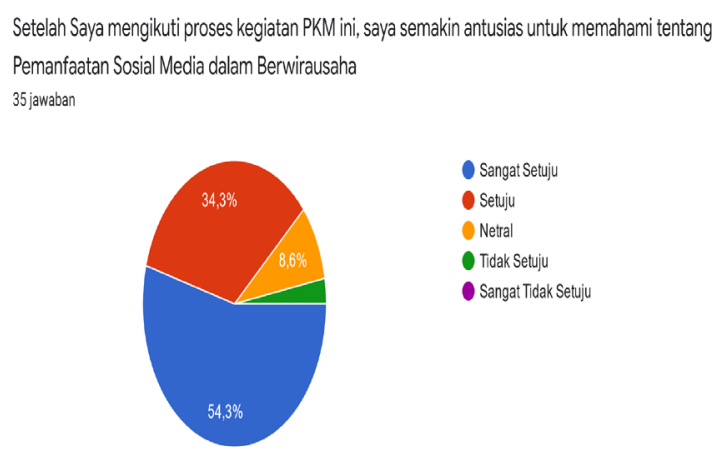

Gambar 11. Kuesioner Setelah Mengikuti Kegiatan

Setelah para peserta didik SMA Negeri 2 Padang Panjang mengikuti kegiatan PKM, ternyata mereka memiliki antusias untuk memahami tentang pemanfaatan sosial media dalam berwirausaha sebesar 54,3\% menjawab sangat setuju. 
Setelah saya mengikuti proses kegiatan PKM ini, pemahaman saya bertambah tentang Pemanfaatan Sosial Media dalam Berwirausaha 35 jawaban
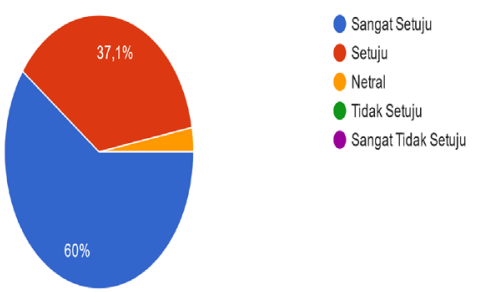

Gambar 12. Kuesioner Setelah Mengikuti Kegiatan

Tabel diatas menjelaskan bahwa sebesar $60 \%$ para peserta didik SMA Negeri 2 Padang Panjang menjawab sangat setuju untuk mengikuti proses kegiatan PKM karena pemahaman mereka bertambah tentang pemanfaatan sosial media dalam berwirausaha.

\section{SIMPULAN}

Pelaksanaan kegiatan pengabdian jarak jauh secara virtual merupakan salah satu cara untuk melakukan penyuluhan kepada peserta didik SMA Negeri 2 Padang Panjang agar mereka termotivasi untuk melakukan bisnis secara online.

Berdasarkan proses kegiatan yang telah dilakukan terhadap para peserta didik SMA Negeri 2 Padang Panjang tentang pentingnya Membangun Jiwa Wirausaha melalui Media Online pada Masa Pandemi Covid-19 sejak usia dini mendapatkan respon yang positif.

Setelah dilakukannya penyampaian materi, para peserta didik sangat antusias dengan memberikan pertanyaan-pertanyaan yang membuat mereka ingin melakukan bisnis secara online.

Dengan adanya sosialisasi dan edukasi tentang pentingnya Membangun Jiwa Wirausaha melalui Media Online pada Masa Pandemi Covid-19 sejak usia dini, khususnya terhadap para peserta didik SMA Negeri 2 Padang Panjang, maka diharapkan mampu membuka cakrawala berpikir peserta didik terhadap tantangan dunia kerja yang akan dihadapi pada masa yang akan datang dan bisa merangsang ide-ide kreatif dalam berinovasi untuk menciptakan sesuatu hal dalam rangka menghadapi revolusi industri 4.0 dan era society 5.0, sehingga mereka dapat menghasilkan sebuah kreatifitas yang unik dan bernilai guna, setelah itu, pada saat menyelesaikan studi mereka nantinya, tidak hanya menunggu mendapatkan pekerjaan, tetapi mampu membuka usaha sendiri dari kreatifitas yang dimilikinya.

\section{UCAPAN TERIMAKASIH}

Kegiatan Pengabdian Kepada Masyarakat Mandiri ini terlaksana, adanya kerjasama yang baik antara Universitas Putra Indonesia YPTK Padang, Sekolah Tinggi Ilmu Ekonomi Perdagangan Padang dengan SMA Negeri 2 Padang Panjang. Kami selaku Tim Pelaksana Pengabdian Kepada Masyarakat Mandiri mengucapkan kepada semua pihak yang telah memfasilitasi kegiatan ini. Harapan ke depannya, semoga terus dapat bekerjasama kembali pada kegiatan berbeda lainnya yang bermanfaat bagi banyak orang.

\section{DAFTAR PUSTAKA}

Buchari, Alma Buchari. 2008. Kewirausahaan, Edisi Revisi. Bandung: Alfabeta.

Drucker, Peter F. 1994. Innovation and Entrepreneurship. New York: Harpercollins Publisher.

Drucker, PeterF. 2015. Kewirausahaan MenurutPeter F Drucker. (http://akarkangkung.blogspot. com/2015/06/kewirausahaan-menurut-peterf-drucker.html, diakses 06 Desember 2021).

Eliza dan Jumiatul. Mulya. 2021. Membangun Jiwa Wirausaha melalui Media Online pada masa Pandemi Covid-19 bagi Peserta Didik SMA Negeri 2 Padang Panjang. Dharmakarya: Jurnal Aplikasi Ipteks untuk Masyarakat. Vol. 10, No. 2, Hal. 91-95.

Eliza, Jumiatul Mulya, dan Nila Pratiwi. 2019. Motivasi Bisnis melalui Kewirausahaan Guna Memberdayakan Koperasi Sekolah sebagai Sarana Berwirausaha bagi Peserta Didik SMA Negeri 2 Padang Panjang. Dharmakarya: Jurnal Aplikasi Ipteks untuk Masyarakat. Vol. 8, No. 4, Hal. 227-230.

Rinaldy, Rudy dan Yosi Suryani. 2021. Performa Ekonomi Kota Padang Tahun 2020. (https:// www.padang.go.id/performa-ekonomi-kotapadang-tahun-2020, diakses 24 September 2021).

Romli, M. Romli. 2012. Buku Jurnalistik Online: Panduan Mengelola Media Online. Bandung: Nuansa.

Suryana. 2003. Kewirausahaan Pedoman Praktis, Kiat dan Proses Menuju Sukses (Edisi Revisi). Jakarta: Salemba Empat. 